\title{
Mono- and Disubstitution Reactions of Gyroscope Like Complexes Derived from Cl-Pt-Cl Rotators within Cage Like Dibridgehead Diphosphine Ligands
}

\author{
Deeb Taher,$\uparrow \S$ Agnieszka J. Nawara-Hultzsch,,+ Nattamai Bhuvanesh, ${ }^{\dagger}$ Frank Hampel,$\ddagger$ \\ John A. Gladysz ${ }^{* \dagger}$ \\ ${ }^{\dagger}$ Department of Chemistry, Texas A\&M University, PO Box 30012, College Station, Texas \\ 77842-3012, USA \\ \$Institut für Organische Chemie and Interdisciplinary Center for Molecular Materials, Friedrich- \\ Alexander-Universität Erlangen-Nürnberg, Henkestraße 42, 91054 Erlangen, Germany
}

\begin{abstract}
Reaction of the gyroscope like complex trans- $\mathrm{Pt}(\mathrm{Cl})_{2}\left(\mathrm{P}\left(\left(\mathrm{CH}_{2}\right)_{14}\right)_{3} \mathrm{P}\right)($ trans-1c) and $p$-tolSeSi-

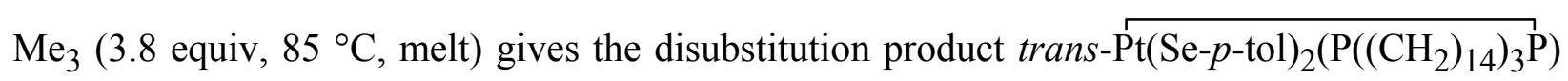
(trans-3c, 63\%) and $\mathrm{ClSiMe}_{3}$. Attempts to access a monochloride complex via monosubstitution were unsuccessful. However, when trans- $\mathrm{Pt}(\mathrm{Ph})_{2}\left(\mathrm{P}\left(\left(\mathrm{CH}_{2}\right)_{n}\right)_{3} \mathrm{P}\right)($ trans-2; $n=\mathbf{c} / 14, \mathbf{e} / 18)$ and $\mathrm{HCl}$ (1.0 equiv; generated from $\mathrm{CH}_{3} \mathrm{COCl}$ and excess $\mathrm{CH}_{3} \mathrm{OH}$ ) are reacted, the monochloride complexes trans- $\mathrm{Pt}(\mathrm{Cl})(\mathrm{Ph})\left(\mathrm{P}\left(\left(\mathrm{CH}_{2}\right)_{n}\right)_{3} \mathrm{P}\right)($ trans-4c,e, 93-96\%) are obtained. These feature dipolar rotators, a common design element in approaches to molecular gyroscopes. The crystal structures of trans-3c and trans-4c are determined, and the radii of the rotators and other geometrical features analyzed, especially with regard to the facility of $\mathrm{PtL}_{2}$ rotation.
\end{abstract}

Keywords: platinum, selenium, gyroscope, substitution, crystal structure

$\S$ Current address: Chemistry Department, The University of Jordan, Amman 11942, Jordan

* Corresponding author. Fax: 979845 5629.E-mail address: gladysz@mail.chem.tamu.edu submitted to J. Organomet. Chem. for the special issue dedicated to Prof. Heinrich Lang dedication: "to a superb mentor of one author (D.T.), and a great friend of another (J.A.G.)" 


\section{(5) INTRODUCTION}

In previous studies, we have developed a rich chemistry associated with the platinum dichloride complexes trans $-\mathrm{Pt}(\mathrm{Cl})_{2}\left(\mathrm{P}\left(\left(\mathrm{CH}_{2}\right)_{n}\right)_{3} \mathrm{P}\right)($ trans $-1 ; n=\mathbf{c} / 14, \mathbf{d} / 16, \mathbf{e} / 18)$ shown in Scheme 1, 1,2 which feature cage like, triply trans spanning dibridgehead diphosphine ligands. A number of related diphosphine complexes with trigonal bipyramidal and octahedral coordination geometries have also been synthesized. ${ }^{3}$ These families of compounds have been termed "gyroscope like", and when the ligands attached to the metals are sufficiently small, rapid rotation occurs within the diphosphine cage. Hence, the $\mathrm{PtCl}_{2}$ or $\mathrm{ML}_{y}$ moieties are commonly referred to as rotators. Interestingly, all of the physics associated with macroscopic gyroscopes remains unaltered at the molecular level. ${ }^{4}$

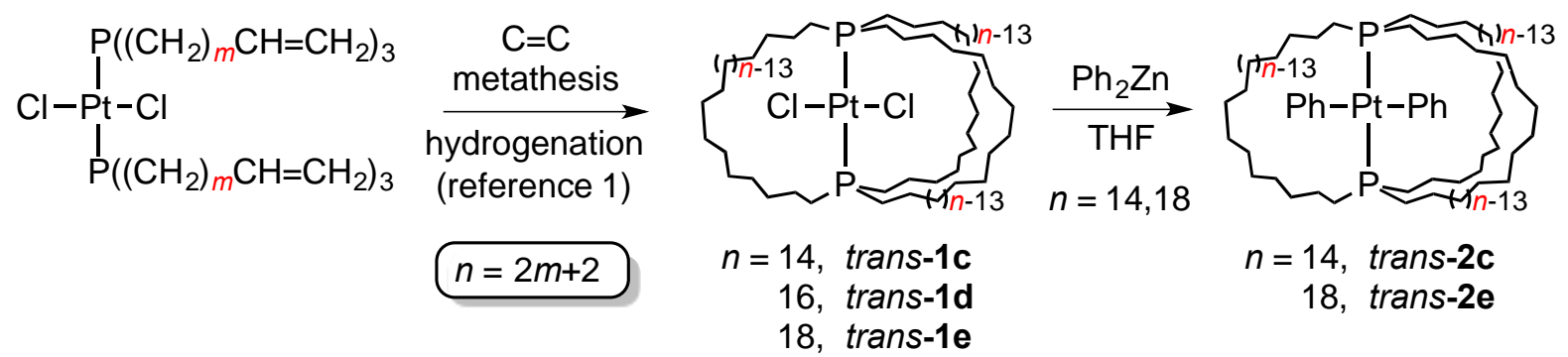

Scheme 1. Syntheses and substitution reaction of the gyroscope like Cl-Pt-Cl complexes trans-1c,e.

In the interest of fine tuning the attendant rotational barriers, various substitution reactions of the $\mathrm{ML}_{y}$ cores have been developed. For example, the chloride ligands in 1c-e can be displaced by a variety of halide and pseudohalide nucleophiles, as well as the phenyl moieties of $\mathrm{ZnPh}_{2}$ to give trans- $\mathrm{Pt}(\mathrm{Ph})_{2}\left(\mathrm{P}\left(\left(\mathrm{CH}_{2}\right)_{n}\right)_{3} \mathrm{P}\right)$ (trans-2c,e; 61-90\%). ${ }^{1,2}$ Rotation of the $\mathrm{PtCl}_{2}$ moieties within the diphosphine cages in 1c-e is rapid on the NMR time scale, even at $-90{ }^{\circ} \mathrm{C}$, as evidenced by a single set of $n / 2 \mathrm{CH}_{2}{ }^{13} \mathrm{C}$ signals. ${ }^{1}$ In contrast, with the diphenyl complex trans-2c, rotation of the $\mathrm{PtPh}_{2}$ moiety is slow, as evidenced by two sets of $n / 2 \mathrm{CH}_{2}{ }^{13} \mathrm{C}$ signals (ca. $2: 1$ area ratios). However, when the methylene chains are lengthened, such as in the higher homolog trans-2e, $\mathrm{PtPh}_{2}$ rotation readily occurs.

Interestingly, large excesses of certain types of nucleophiles, such as acetylide, cyanide, or related ${ }^{-} \mathrm{C} \equiv \mathrm{X}$ species, displace the dibridgehead diphosphine from platinum. ${ }^{1,2}$ In some cases, 
salts of the platinum dianion $\left[\mathrm{Pt}(\mathrm{C} \equiv \mathrm{X})_{4}\right]^{2-}$ have been isolated. ${ }^{2}$ Adducts with $\mathrm{Rh}(\mathrm{CO})(\mathrm{Cl})$ rotators can be similarly excised with excess $\mathrm{PMe}_{3} \cdot{ }^{3 \mathrm{f}}$ Other types of substitution reactions (below) are believed to involve initial electron transfer. $3 \mathrm{~g}$

Against this backdrop, we have sought to expand the palette of chloride ligand substitution reactions applicable to trans-1c-e or their derivatives. One goal has been to apply a greater range of heteronucleophiles. Another has been to develop routes to monosubstitution products. An incentive for the latter involves potential applications of complexes possessing unsymmetrically substituted or "dipolar" rotators, $\mathrm{X}-\mathrm{Pt}-\mathrm{X}$ '. Rotation of the $\mathrm{PtCl}_{2}$ moieties in trans-1c-e is Brownian, meaning that clockwise and counterclockwise directions are equally probable. However, dipolar rotators can, in principle, be (1) oriented in a static electric field, and (2) induced to spin unidirectionally by a rotating electric field of appropriate frequency. 4,5 The latter would constitute a functional molecular gyroscope, which has been an ongoing quest in several research groups. 6,7

\section{(5) RESULTS}

A few sulfur substituted gyroscope like complexes have been prepared, although in some cases workups have proved problematic. ${ }^{1,8}$ Selenium analogs would provide a larger steric footprint and perhaps enhanced crystallinity. A variety of alkyl and aryl selenium nucleophiles have been shown to displace transition metal halides. ${ }^{9,10}$ Among these, trimethylsilylated species have proven to be convenient and effective. ${ }^{9}$ Since only a volatile trimethylsilyl halide coproduct is generated, workups should be facilitated.

Thus, as shown in Scheme 2, trans-1c and the easily prepared $p$-tolylselenium compound $p$-tolSeSiMe $3(3.8 \text { equiv })^{11}$ were combined in THF at room temperature. The sample was periodically monitored by ${ }^{31} \mathrm{P}$ NMR. After $18 \mathrm{~h}$, the sample was warmed to $50{ }^{\circ} \mathrm{C}$. After an additional $16 \mathrm{~h}$, no reaction had occurred. Thus, trans-1c and $p$-tolSeSiMe 3 were combined as solids, and the sample transferred to a $85^{\circ} \mathrm{C}$ oil bath. The sample melted, giving a free flowing yellow liquid. Workup afforded the target complex trans- $\mathrm{Pt}(\mathrm{Se}-p \text {-tol })_{2}\left(\mathrm{P}\left(\left(\mathrm{CH}_{2}\right)_{14}\right)_{3} \mathrm{P}\right)($ trans-3c) in $63 \%$ yield as an air stable polycrystalline solid. 


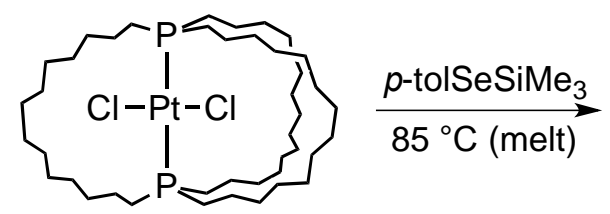

trans-1c

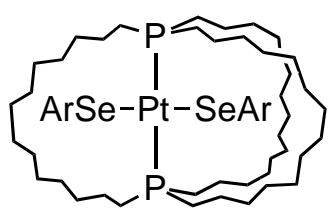

trans-3c

$(63 \%)$

$\mathrm{Ar}=p$-tol

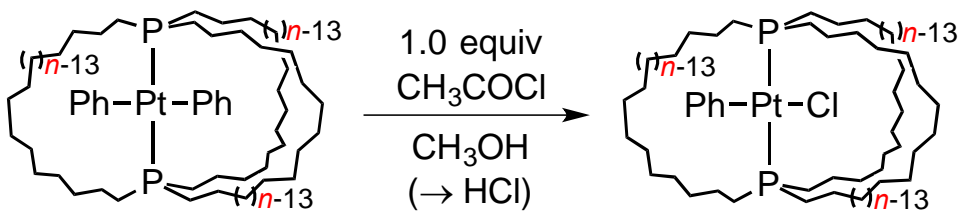

$n=14$, trans-2c

18, trans-2e

$n=14$, trans $-4 \mathrm{c}(93 \%)$

18 , trans-4e $(98 \%)$

Scheme 2. New substitution chemistry of gyroscope like $\mathrm{PtCl}_{2}$ and $\mathrm{PtPh}_{2}$ complexes.

Complex trans-3c was characterized by $\mathrm{NMR}\left({ }^{1} \mathrm{H},{ }^{13} \mathrm{C},{ }^{31} \mathrm{P},{ }^{195} \mathrm{Pt}\right)$, mass spectrometry, and microanalysis, as summarized in the experimental section. The mass spectrum showed the expected molecular ion. The ${ }^{13} \mathrm{C}$ NMR spectrum exhibited $n(14)$ as opposed to $n / 2(7) \mathrm{CH}_{2}$ signals, indicating two inequivalent methylene chains $(2: 1)$. Thus, $\mathrm{Pt}(\mathrm{Se}-\mathrm{p} \text {-tol })_{2}$ rotation through the seventeen membered macrocycles must be slow on the NMR time scale or blocked completely, analogous to the situation with trans-2c noted above. As seen with 1c, the $\mathrm{PCH}_{2} \mathrm{CH}_{2} \mathrm{CH}_{2}$ signals were virtual triplets; other NMR features were routine.

Numerous attempts to develop conditions that would give a monosubstitution product with a dipolar Cl-Pt-Se-p-tol rotator were unsuccessful. Thus, an alternative desymmetrization approach involving electrophilic agents was considered. It has previously been shown that dialkyl and diaryl platinum(II) complexes can be selectively converted to monoalkyl or monoaryl platinum monochloride complexes when treated with $\mathrm{HCl}{ }^{12}$ The electron withdrawing chloride ligand in the initial product renders it less basic (nucleophilic) than the precursor. This retards further conversion of the monochloride complex to a dichloride complex.

Thus, as shown in Scheme 2, $\mathrm{CH}_{2} \mathrm{Cl}_{2}$ solutions of trans-2c,e were treated with $\mathrm{HCl}(1.0$ equiv). In practice, this was accomplished by adding a stoichiometric amount of the acid chloride $\mathrm{CH}_{3} \mathrm{COCl}$ and an excess of $\mathrm{CH}_{3} \mathrm{OH}$. After brief intervals, ${ }^{31} \mathrm{P}$ NMR spectra showed very high 
conversions to a single new product. Workups gave the target monochloride complexes trans$\mathrm{Pt}(\mathrm{Cl})(\mathrm{Ph})\left(\mathrm{P}\left(\left(\mathrm{CH}_{2}\right)_{n}\right)_{3} \mathrm{P}\right)($ trans $-4 ; n=\mathbf{c} / 14, \mathbf{e} / 18)$ as cream colored powders in $95-98 \%$ yields. These showed no decomposition when stored in air over an extended period of time.

Complexes trans-4c,e were characterized analogously to trans-3c. Most features were unexceptional. Interestingly, both showed a single set of $n / 2 \mathrm{CH}_{2}{ }^{13} \mathrm{C}$ NMR signals. Thus, the diphenyl complex trans-2c and the monophenyl monochloride complex trans-4c exhibit different limits with respect to $\mathrm{PtPh}_{2}$ or $\mathrm{PtClPh}$ rotation, a dichotomy that is analyzed in the discussion section. An attempt to effect a conceptually similar desymmetrization of trans-3c by reaction with $\mathrm{CH}_{3} \mathrm{COCl}$ (1.0 equiv) did not lead to tractable products.

Single crystals of trans $\mathbf{- 3 c}$ and trans $\mathbf{- 4 c}$ could be obtained as described in the experimental section. The crystal structures were determined as summarized in Table 1 and the experimental section. Thermal ellipsoid diagrams and key metrical parameters are provided in Figures 1 and 2. For both structures, the angles defined by the least squares planes of the aryl rings and the PPt-P vector were calculated. In trans-3c, the tolyl groups were skewed $\left(45.08^{\circ}, 48.84^{\circ}\right)$, whereas in trans-4c the phenyl group was nearly perpendicular $\left(85.55^{\circ}\right)$. The crystal structures of trans-


Figure 1. Thermal ellipsoid plots of the molecular structure of trans-3c (50\% probability level). Key interatomic distances $(\AA)$ and angles $\left({ }^{\circ}\right)$ : Pt1-P1 2.3168(9), Pt1-P2 2.3207(9), Pt1-Se1 2.4684(4), Pt1-Se2 2.4650(5), Pt1-C49 7.394, Pt1-C56 7.368, P1-Pt1-P2 176.59(3), Se1-Pt1-Se2 176.012(14), P1-Pt1-Se1 93.99(2), P1-Pt1-Se2 86.04(2), P2-Pt1-Se1 85.92(2), P2-Pt1-Se2 93.81(2), C43-Se1-Pt1 105.90(10), C50-Se2-Pt1 105.75(11). 

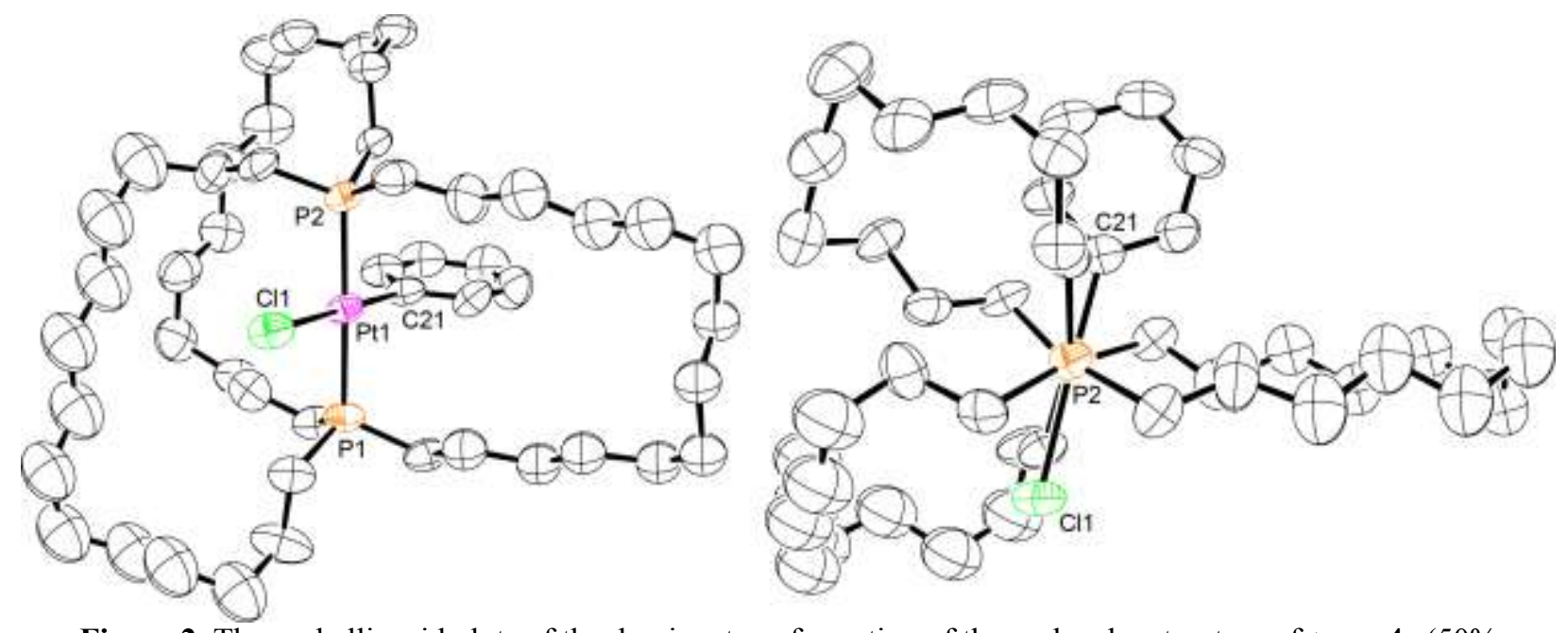

Figure 2. Thermal ellipsoid plots of the dominant conformation of the molecular structure of trans $-\mathbf{4 c}(50 \%$ probability level). Key interatomic distances $(\AA)$ and angles $\left(^{\circ}\right)$ : Pt-P1 2.3025(15), Pt-P2 2.2968(14), Pt-C11 2.3871(15), Pt-C21 2.006(6), Pt-H para 5.781, P1-Pt-P2 176.86(5), Cl-Pt-C21 178.62(19)

2c,e exhibited analogous phenyl ring conformations. The other metrical parameters associated with the new complexes were routine, resembling those found in related species earlier. For example, the Pt-Se-C angles $\left(105.90(10)^{\circ}-105.75(11)^{\circ}\right)$ were near the average of those in six other platinum(II) complexes with two Pt-Se-C linkages $\left(107.6^{\circ}\right) .{ }^{10 \mathrm{a}}$

\section{(5) DISCUSSION}

The substitution reactions described above allow access to new types of platinum gyroscope like complexes and can presumably be extended to other metal fragments. Only a few methods have so far been developed by which a dipole moment can be introduced on a rotator that lacks one. In other cases, the ring closing metatheses in Scheme 1 are carried out on educts where the $\mathrm{ML}_{y}$ unit already has a dipole moment, such as $\mathrm{Rh}(\mathrm{CO})(\mathrm{Cl})$ or $\operatorname{Re}(\mathrm{CO})_{3}(\mathrm{Cl}) .{ }^{3 \mathrm{c}, \mathrm{d}} \mathrm{An}-$ other type of substitution reaction that has been used to desymmetrize a nonpolar rotator is shown in Scheme 3. ${ }^{3 \mathrm{a}, \mathrm{h}}$ This is believed to involve initial electron transfer from iron to $\mathrm{NO}^{+}$, generating an intermediate radical cation.

The conformations of the rotators in Figures 1 and 2 closely approximate those that would be expected in the ground states, as depicted in $\mathbf{I}$ in Figure 3. All rotators are characterized by a radius. That of the $\mathrm{PtCl}_{2}$ moiety in trans-1c is the sum of the platinum-chloride distance and the van der Waals radius of chlorine $(1.75 \AA),{ }^{13}$ or approximately $4.05-4.06 \AA .{ }^{1}$ As analyzed 

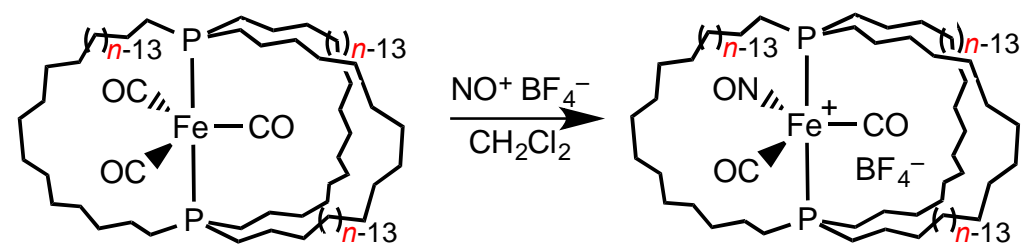

$$
\begin{array}{r}
\mathrm{n}=10, \mathbf{5} \mathbf{a}^{+} \mathrm{BF}_{4}-, 98 \% \\
12, \mathbf{5 b}^{+} \mathrm{BF}_{4}^{-}, 89 \% \\
14, \mathbf{5 c}^{+} \mathrm{BF}_{4}^{-}, 81 \%
\end{array}
$$

Scheme 3. Other substitution reactions of gyroscope like complexes leading to dipolar rotators.

previously, the radius of a $\mathrm{PtPh}_{2}$ moiety is ca. 7.07-7.08 $\AA .^{1}$ The radius of the rotator in trans-3c was taken as the sum of the distance from platinum to the $p$-methyl groups (7.37-7.39 $\AA$ ), plus the van der Waals radius of an $\mathrm{sp}^{3}$ hybridized carbon atom $(1.70 \AA),{ }^{13}$ or 9.07-9.09 $\AA$.

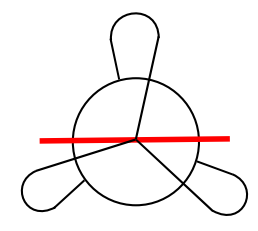

I



II

Figure 3. Newman type projections of the energy minima (I) and maxima (II) associated with rotation of the rotator in square planar gyroscope like complexes.

The crystal structures of a variety of complexes of the formula trans- $\overline{\mathrm{Pt}(\mathrm{L})_{2}\left(\mathrm{P}\left(\left(\mathrm{CH}_{2}\right)_{14}\right)_{3} \text { - }\right.}$ P) have been determined. ${ }^{1}$ These feature seventeen membered macrocycles like the new structures in Figures 1 and 2. It is a simple matter to compute the distances from the metal to the two carbon atoms of each macrocycle closest to the plane of the rotators, and/or the most distant carbon atoms. As diagrammed elsewhere, ${ }^{1 b, 3 g, h}$ the van der Waals radius of the carbon atom is then subtracted to give an estimate of the "horizontal clearance" for the rotators. Naturally, as evident in Figure 1, the conformations of the macrocycles differ, resulting in different clearances. Often the minimum value is taken as the starting point for analysis, but other treatments, such as average values, can be considered. In the case of trans-1c, the values range from $3.76 \AA$ to $5.75 \AA$. Those for trans-2c vary from $3.51 \AA$ to $6.09 \AA$. In the case of trans-2e, which features twentyone membered macrocycles, the values range from $4.22 \AA$ to $8.79 \AA .{ }^{1 b}$

In square planar gyroscope like complexes, the transition states for rotation would normally involve passage of one ligand of a rotator through a single macrocycle, as shown in II. There will be six such maxima as the rotator passes through $360^{\circ}$. With respect to selenium substituted 
trans $\mathbf{- 3 c}$, it is evident that the radius of the rotator greatly exceeds the maximum extension or clearance possible with seventeen membered macrocycles (9.07-9.09 $\AA$ vs. ca. $6.09 \AA$ ). With respect to the previously studied diphenyl complex trans-2e, the facile $\mathrm{PtPh}_{2}$ rotation needs to be viewed in the context of the maximum extension or clearance possible in a twentyone membered macrocycle (8.79 $\AA$ vs. 7.07-7.08 $\AA$ radius). The macrocycles do not remain rigid as the $\mathrm{PtPh}_{2}$ moiety rotates; rather, they undergo correlated conformational changes, which would enable the macrocycle thorough which the phenyl group is passing (see II) to be maximally extended.

The surprise regarding the new compound trans $\mathbf{- 4 c}$ is that $\mathrm{PtClPh}$ rotation through the seventeen membered ring is rapid on the NMR time scale at room temperature, but $\mathrm{PtPh}_{2}$ rotation in trans-2c is not. The horizontal clearances imposed by the methylene chains in crystalline trans-4c $(3.17 \AA \text { to } 6.28 \AA)^{14}$ are similar to those in trans-2c $(3.51 \AA$ to $6.09 \AA)$. Hence, the barrier is not a strict function of the radius of the rotator, which is the same in both cases. In this context, NMR spectra of trans-2c further indicate that rotation about the $\mathrm{Pt}-\mathrm{Ph}$ bonds is restricted, as evidenced by two ortho and two meta ${ }^{13} \mathrm{C}$ signals. Only one set of signals is observed with trans-4c. Thus, there appears to be more extensive interactions of the phenyl rings with the cage like diphosphine in trans-2c. In any case, with trans-4c a rotator of radius 7.02-7.03 $\AA$ is able to pass through macrocycles for which the maximum solid state clearance is $6.28 \AA .{ }^{14}$

In summary, this study has expanded the toolbox of substitution reactions applicable to gyroscope like complexes, and provided additional data and insight regarding their dynamic properties. Future efforts will extend these themes to additional coordination geometries, ${ }^{3 g}$ including syntheses of other types of complexes with dipolar rotators, and minimization of the rotational barriers therein. 


\section{Experimental Section}

General. Reactions were conducted under dry inert atmospheres using solvents and materials detailed in the previous full paper. ${ }^{1 \mathrm{~b}}$ Instruments employed were identical with those listed in the previous full paper. ${ }^{1 b}$

trans-Pt(Se-p-tol $)_{2}\left(\mathbf{P}\left(\left(\mathrm{CH}_{2}\right)_{14}\right)_{3} \mathbf{P}\right)$ (trans-3c). A Schlenk tube was charged with trans$\mathrm{Pt}(\mathrm{Cl})_{2}\left(\mathrm{P}\left(\left(\mathrm{CH}_{2}\right)_{14}\right)_{3} \mathrm{P}\right)\left(\right.$ trans-1c; $\left.{ }^{1 \mathrm{~b}} 0.100 \mathrm{~g}, 0.109 \mathrm{mmol}\right)$ and $p$-tolSeSiMe $3(0.100 \mathrm{~g}, 0.411$ mmol), ${ }^{9}$ and was partially evacuated. The tube was placed in an $85{ }^{\circ} \mathrm{C}$ oil bath, whereupon the solids melted to yield a yellow, free-flowing liquid. After $18 \mathrm{~h}$, the mixture had become a yellow solid and was cooled to room temperature. Any residual $\mathrm{Me}_{3} \mathrm{SiCl}$ was removed in vacuo, and the residue was washed with pentane. Crystallization from pentane/dichloromethane $(3 \mathrm{~mL}, 1: 1 \mathrm{v} / \mathrm{v})$ gave the solvate trans-3c $\cdot 0.33 \mathrm{CH}_{2} \mathrm{Cl}_{2}$ as a yellow, air stable polycrystalline solid $(0.084 \mathrm{~g}, 0.071$ mmol, 65\%), dec. pt. $125{ }^{\circ} \mathrm{C}$ (yellow solid to orange solid). Anal. Calcd for $\mathrm{C}_{56} \mathrm{H}_{98} \mathrm{P}_{2-}$ $\mathrm{PtSe}_{2} \cdot 0.33 \mathrm{CH}_{2} \mathrm{Cl}_{2}: \mathrm{C}, 55.70 ; \mathrm{H}, 8.19$; found: C, 55.60; H, 8.47. MS: ${ }^{15 \mathrm{a}} 1186.5724\left([M]^{+}, 14 \%\right)$, $1015.5921\left(\left[M-\mathrm{SeC}_{6} \mathrm{H}_{4} \mathrm{CH}_{3}\right]^{+}, 9 \%\right)$.

$\operatorname{NMR}\left(\mathrm{CDCl}_{3}, \delta(\mathrm{ppm})\right):{ }^{16}{ }^{1} \mathrm{H}(500 \mathrm{MHz}) 7.53\left(\mathrm{~d},{ }^{3} J_{\mathrm{HH}}=10 \mathrm{~Hz}, 4 \mathrm{H}\right.$ of $\left.2 \mathrm{C}_{6} \mathrm{H}_{4}\right), 6.86(\mathrm{~d}$, ${ }^{3} J_{\mathrm{HH}}=10 \mathrm{~Hz}, 4 \mathrm{H}$ of $\left.2 \mathrm{C}_{6} \mathrm{H}_{4}\right), 5.30\left(\mathrm{~s}, 0.67 \mathrm{H}, 0.33 \mathrm{CH}_{2} \mathrm{Cl}_{2}\right), 2.52-2.46\left(\mathrm{~m}, 4 \mathrm{H}, \mathrm{PCH}_{2}\right), 2.25(\mathrm{~s}$, $\left.6 \mathrm{H}, \mathrm{CH}_{3}\right), 1.65-1.78\left(\mathrm{~m}, 8 \mathrm{H}, \mathrm{CH}_{2}\right), 1.51-1.20\left(\mathrm{~m}, 70 \mathrm{H}, \mathrm{CH}_{2}\right), 0.89-0.86\left(\mathrm{~m}, 2 \mathrm{H}, \mathrm{CH}_{2}\right) ;{ }^{13} \mathrm{C}\left\{{ }^{1} \mathrm{H}\right\}$ $(126 \mathrm{MHz}) \mathrm{C}_{6} \mathrm{H}_{4}$ at $134.9\left(\mathrm{~s}, J_{\mathrm{CSe}}=30.0 \mathrm{~Hz}\right),{ }^{17} 133.3,133.1$, and $128.8(3 \times \mathrm{s}) ; 31.0$ (virtual t, ${ }^{18}$ $\left.J_{\mathrm{CP}}=7.8 \mathrm{~Hz}, \mathrm{PCH}_{2} \mathrm{CH}_{2} \mathrm{CH}_{2}\right), 29.6$ (virtual t, $\left.{ }^{18} J_{\mathrm{CP}}=6.6 \mathrm{~Hz}, \mathrm{PCH}_{2} \mathrm{CH}_{2} \mathrm{CH}_{2}\right), 29.0\left(\mathrm{~s}, \mathrm{CH}_{3}\right)$, $28.9\left(\mathrm{~s}, \mathrm{CH}_{2}\right), 28.6\left(\mathrm{~s}, \mathrm{CH}_{2}\right), 28.3\left(\mathrm{~s}, \mathrm{CH}_{2}\right), 28.0\left(\mathrm{~s}, \mathrm{CH}_{2}\right), 27.9\left(\mathrm{~s}, \mathrm{CH}_{2}\right), 26.8\left(\mathrm{~s}, \mathrm{CH}_{2}\right), 26.7(\mathrm{~s}$, $\left.\mathrm{CH}_{2}\right), 25.9\left(\mathrm{~s}, \mathrm{PCH}_{2} \mathrm{CH}_{2}\right), 25.5$ (virtual t, $\left.{ }^{18} \mathrm{~J}_{\mathrm{CP}}=17.0 \mathrm{~Hz}, \mathrm{PCH}_{2}\right), 22.7\left(\mathrm{~s}, \mathrm{PCH}_{2} \mathrm{CH}_{2}\right), 21.2(\mathrm{~s}$, $\left.\mathrm{CH}_{2}\right), 20.9$ (virtual t, $\left.{ }^{18} J_{\mathrm{CP}}=17.1 \mathrm{~Hz}, \mathrm{PCH}_{2}\right) ;{ }^{31} \mathrm{P}\left\{{ }^{1} \mathrm{H}\right\}(202 \mathrm{MHz}) 1.4\left(\mathrm{~s},{ }^{1} J_{\mathrm{PPt}}=2516 \mathrm{~Hz}\right)$, ${ }^{195} \mathrm{Pt}\left\{{ }^{1} \mathrm{H}\right\}(202 \mathrm{MHz})-4879.7\left(\mathrm{~s},{ }^{1} J_{\mathrm{PtP}}=2509 \mathrm{~Hz}\right) .{ }^{19,20}$

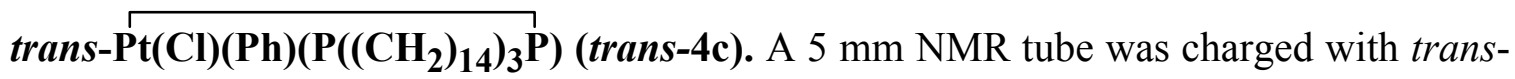
$\mathrm{Pt}(\mathrm{Ph})_{2}\left(\mathrm{P}\left(\left(\mathrm{CH}_{2}\right)_{14}\right)_{3} \mathrm{P}\right)\left(\right.$ trans-2c; $\left.{ }^{1} 0.0378 \mathrm{~g}, 0.0378 \mathrm{mmol}\right), \mathrm{CH}_{2} \mathrm{Cl}_{2}(0.40 \mathrm{~mL}), \mathrm{CH}_{3} \mathrm{OH}(0.10$ $\mathrm{mL})$, and $\mathrm{CH}_{3} \mathrm{COCl}(0.0033 \mathrm{~mL}, 0.0378 \mathrm{mmol})$. After $5 \mathrm{~min},{ }^{31} \mathrm{P}\left\{{ }^{1} \mathrm{H}\right\} \mathrm{NMR}$ spectrum showed $>99 \%$ conversion. The solvent was removed by oil pump vacuum, and benzene was added to the 
residue. The suspension was filtered through a pipette packed with silica gel, which was rinsed with benzene. The solvent was removed from the filtrate by freeze pump drying to give trans-4c as a cream colored powder $(0.0339 \mathrm{~g}, 0.0354 \mathrm{mmol}, 93 \%)$. DSC $\left(\mathrm{T}_{i} / \mathrm{T}_{e} / \mathrm{T}_{p} / \mathrm{T}_{c} / \mathrm{T}_{f}\right):{ }^{21} 142.0 / 190.6 /$ 196.7/198.3/206. ${ }^{\circ} \mathrm{C}$ (endotherm). TGA: onset of mass loss, $254^{\circ} \mathrm{C}$. Anal. Calcd. for $\mathrm{C}_{48} \mathrm{H}_{89} \mathrm{Cl}-$ $\mathrm{P}_{2} \mathrm{Pt}$ : C, 60.14; H, 9.36. Found: C, 59.85; H, 9.61. IR ( $\mathrm{cm}^{-1}$, powder film): 2922 (s), 2853 (s), $1571(\mathrm{w}), 1455$ (m), 1262 (w), 1100 (m), 1023 (w), 799 (m), 733 (s), 702 (s). MS: ${ }^{15 b} 923$ ([M$\left.\mathrm{Cl}]^{+}, 70 \%\right)$.

$\operatorname{NMR}\left(\delta(\mathrm{ppm}), \mathrm{CDCl}_{3}\right):{ }^{16}{ }^{1} \mathrm{H}(400 \mathrm{MHz}) 7.23\left(\mathrm{~d},{ }^{1} J_{\mathrm{HH}}=7.4 \mathrm{~Hz}, 2 \mathrm{H}, o-\mathrm{Ph}\right), 6.89($ apparent t, $\left.{ }^{1} J_{\mathrm{HH}}=7.0 \mathrm{~Hz}, 2 \mathrm{H}, m-\mathrm{Ph}\right), 6.81\left(\right.$ apparent t $\left.,{ }^{1} J_{\mathrm{HH}}=7.1 \mathrm{~Hz}, 1 \mathrm{H}, p-\mathrm{Ph}\right), 1.72-1.62(\mathrm{br} \mathrm{m}$, $12 \mathrm{H}, \mathrm{PCH}_{2}$ ), $1.55-1.46$ (br m, $12 \mathrm{H}, \mathrm{PCH}_{2} \mathrm{CH}_{2}$ ), 1.45-1.36 (br m, $12 \mathrm{H}, \mathrm{PCH}_{2} \mathrm{CH}_{2} \mathrm{CH}_{2}$ ), 1.331.25 (br m, 48H, remaining $\left.\mathrm{CH}_{2}\right),{ }^{13} \mathrm{C}\left\{{ }^{1} \mathrm{H}\right\}(100 \mathrm{MHz}) 138.2(\mathrm{~s}, i-\mathrm{Ph}),{ }^{22} 137.4(\mathrm{~s}, o-\mathrm{Ph}), 127.3$ (s, $m-\mathrm{Ph}$ ), $121.6\left(\mathrm{~s}, p-\mathrm{Ph}\right.$ ), 29.7 (virtual t, ${ }^{18} J_{\mathrm{CP}}=6.8 \mathrm{~Hz}, \mathrm{PCH}_{2} \mathrm{CH}_{2} \mathrm{CH}_{2}$ ), 29.2 (virtual t, ${ }^{18} J_{\mathrm{CP}}=$ $\left.6.7 \mathrm{~Hz}, \mathrm{PCH}_{2} \mathrm{CH}_{2} \mathrm{CH}_{2}\right), 28.6\left(\mathrm{~s}, \mathrm{CH}_{2}\right), 28.2\left(\mathrm{~s}, \mathrm{CH}_{2}\right), 27.3\left(\mathrm{~s}, \mathrm{CH}_{2}\right), 26.7\left(\mathrm{~s}, \mathrm{CH}_{2}\right), 26.6(\mathrm{~s}$, $\mathrm{CH}_{2}$ ), $26.3\left(\mathrm{~s}, \mathrm{CH}_{2}\right), 23.2\left(\mathrm{~s}, \mathrm{CH}_{2}\right), 21.7$ (virtual t, ${ }^{18} J_{\mathrm{CP}}=15.7 \mathrm{~Hz}, \mathrm{PCH}_{2}$ ), 19.3 (virtual t, ${ }^{18} J_{\mathrm{CP}}$ $=16.0 \mathrm{~Hz}, \mathrm{PCH} 2) ;{ }^{31} \mathrm{P}\left\{{ }^{1} \mathrm{H}\right\}(162 \mathrm{MHz}) 7.8\left(\mathrm{~s},{ }^{1} J_{\mathrm{PPt}}=2798 \mathrm{~Hz}\right) .{ }^{20}$

trans-Pt(Cl)(Ph)(P((CH2) 18) $\left.{ }_{3} \mathbf{P}\right)($ trans-4e). A $5 \mathrm{~mm}$ NMR tube was charged with trans$\mathrm{Pt}(\mathrm{Ph})_{2}\left(\mathrm{P}\left(\left(\mathrm{CH}_{2}\right)_{18}\right)_{3} \mathrm{P}\right)\left(\right.$ trans $\left.-2 \mathrm{e} ;{ }^{1} 0.0159 \mathrm{~g}, 0.0136 \mathrm{mmol}\right), \mathrm{CH}_{2} \mathrm{Cl}_{2} / \mathrm{CH}_{3} \mathrm{OH}(0.75 \mathrm{~mL}, 2: 1 \mathrm{v} / \mathrm{v})$, and $\mathrm{CH}_{3} \mathrm{COCl}(0.0117 \mathrm{~mL}, 0.0136 \mathrm{mmol})$. After $1 \mathrm{~h}, \mathrm{a}{ }^{31} \mathrm{P}\left\{{ }^{1} \mathrm{H}\right\}$ NMR spectrum showed $>99 \%$ conversion. The solvent was removed by oil pump vacuum, and benzene was added to the residue. The suspension was filtered through a pipette packed with glass fibers. The pipette was rinsed with benzene. The solvent was removed by freeze pump drying to give trans-4e as a cream-colored powder (0.0142 g, $0.0121 \mathrm{mmol}, 98 \%)$. DSC: $\left(\mathrm{T}_{i} / \mathrm{T}_{e} / \mathrm{T}_{p} / \mathrm{T}_{c} / \mathrm{T}_{f}\right):^{21} 31.1 / 31.1 / 33.6 /$ 36.8/37.2 (endotherm), 49.2/75.9/ 81.3/83.6/86.5 (endotherm), 87.1/94.4/99.3/102.5/105.0 (endotherm). TGA: onset of mass loss, $190{ }^{\circ} \mathrm{C}$. Anal. Calcd. for $\mathrm{C}_{60} \mathrm{H}_{113} \mathrm{ClP}_{2} \mathrm{Pt}$ : C, 63.94; H, 10.11. Found: C, 64.14; H, 10.23. IR (cm ${ }^{-1}$, powder film): 2922 (s), 2853 (s), 1571 (w), 1463 (m), 1370 (w), $1262(\mathrm{w}), 1100(\mathrm{~m}), 1027(\mathrm{~m}), 795(\mathrm{~m}), 702(\mathrm{~m}) . \mathrm{MS}:{ }^{15 b} 1091\left([M-\mathrm{Cl}]^{+}, 80 \%\right)$.

$\operatorname{NMR}\left(\delta(\mathrm{ppm}), \mathrm{CDCl}_{3}\right):{ }^{16}{ }^{1} \mathrm{H}(400 \mathrm{MHz}) 7.23\left(\mathrm{~d},{ }^{1} J_{\mathrm{HH}}=7.4 \mathrm{~Hz}, 2 \mathrm{H}, o-\mathrm{Ph}\right), 6.87$ (appar- 
ent t, $\left.{ }^{1} J_{\mathrm{HH}}=6.7 \mathrm{~Hz}, 2 \mathrm{H}, m-\mathrm{Ph}\right), 6.81\left(\right.$ apparent t, $\left.{ }^{1} J_{\mathrm{HH}}=7.2 \mathrm{~Hz}, 1 \mathrm{H}, p-\mathrm{Ph}\right), 1.50-1.31(\mathrm{br} \mathrm{m}$, 30H, $\left.\mathrm{CH}_{2}\right), 1.31-1.04$ (br m, 78H, $\left.\mathrm{CH}_{2}\right) ;{ }^{13} \mathrm{C}\left\{{ }^{1} \mathrm{H}\right\}^{23}(100 \mathrm{MHz}) 137.2(\mathrm{~s}, o-\mathrm{Ph}), 127.6(\mathrm{~s}, m-\mathrm{Ph})$, $121.5(\mathrm{~s}, p-\mathrm{Ph}), 30.5$ (virtual t, $\left.{ }^{18}{ }^{3} J_{\mathrm{CP}}=6.2 \mathrm{~Hz}, \mathrm{PCH}_{2} \mathrm{CH}_{2} \mathrm{CH}_{2}\right), 28.5\left(\mathrm{~s}, \mathrm{CH}_{2}\right), 28.4\left(\mathrm{~s}, \mathrm{CH}_{2}\right)$, $28.32\left(\mathrm{~s}, \mathrm{CH}_{2}\right), 28.29\left(\mathrm{~s}, \mathrm{CH}_{2}\right), 28.0\left(\mathrm{~s}, \mathrm{CH}_{2}\right), 27.8\left(\mathrm{~s}, \mathrm{CH}_{2}\right), 23.4\left(\mathrm{~s}, \mathrm{PCH}_{2} \mathrm{CH}_{2}\right), 21.2$ (virtual $\left.\mathrm{t},{ }^{18}{ }^{1} J_{\mathrm{CP}}=15.8 \mathrm{~Hz}, \mathrm{PCH} 2\right) ;{ }^{31} \mathrm{P}\left\{{ }^{1} \mathrm{H}\right\}(162 \mathrm{MHz}) 7.1\left(\mathrm{~s},{ }^{1} J_{\mathrm{PPt}}=2774 \mathrm{~Hz}\right) .{ }^{20}$

Crystallography. A. Light yellow plates of trans-3c were obtained by the slow evaporation of a $\mathrm{CHCl}_{3} / \mathrm{CH}_{2} \mathrm{Cl}_{2}$ solution $(1: 1 \mathrm{v} / \mathrm{v}$, room temperature). Data were collected on a two component twin as outlined in Table 1. Cell parameters were determined from 60 data frames taken at $0.5^{\circ}$ widths. Integrated intensity information for each reflection (for both twins) was obtained by reduction of the data frames with the program APEX2. ${ }^{24}$ Data were corrected for Lorentz, polarization, and crystal decay effects. The program TWINABS ${ }^{25}$ was used to correct for absorption. Systematic reflection conditions and statistical tests of the data suggested the space group $P-1$. The structure was solved by direct methods using SHELXTL (XS). ${ }^{26}$ Hydrogen atoms were placed in idealized positions and refined using a riding model. Non-hydrogen atoms were refined with anisotropic thermal parameters. The absence of additional symmetry and voids were confirmed using PLATON (ADDSYM). ${ }^{27}$ The structure was refined (weighted least squares refinement on $\mathrm{F}^{2}$ ) to convergence. ${ }^{26,28} \mathbf{B} . \mathrm{CH}_{2} \mathrm{Cl}_{2}$ was added to a pentane suspension of trans-4c until the sample became homogeneous. The mixture was allowed to slowly concentrate to ca. $50 \%$ of the original volume (room temperature). After one day, colorless cubes of trans-4c had formed. Data were collected as outlined in Table 1. Cell parameters were obtained from 10 frames using a $10^{\circ}$ scan and refined with 5952 reflections. Lorentz, polarization, and absorption corrections were applied. ${ }^{29}$ The space group was determined from systematic absences and subsequent least-squares refinement. The structure was solved by direct methods. The parameters were refined with all data by full-matrix-least-squares on $F^{2}$ using SHELXL-97. ${ }^{26}$ Non-hydrogen atoms were refined with anisotropic thermal parameters. The hydrogen atoms were fixed in idealized positions using a riding model. Scattering factors were taken from the literature. ${ }^{30}$ Three methylene carbon atoms were disordered and were refined to a 67:33 occupancy ratio. 


\section{Acknowledgment}

The authors thank the U.S. National Science Foundation (CHE-1153085), the Fulbright Foundation (D.T.), and the University of Jordan (D.T) for support, and Dr. Tobias Fiedler, Ms. Georgette Lang, and Mr. Alex Estrada for technical assistance.

\section{Appendix A. Supplementary material}

CCDC 1450263 and 955809 contain the supplementary crystallographic data for trans-3a and trans-4a. These data can be obtained free of charge from The Cambridge Crystallographic Data Centre via www.ccdc. cam.ac.uk/data_request/cif .

TABLE OF CONTENTS GRAPHIC

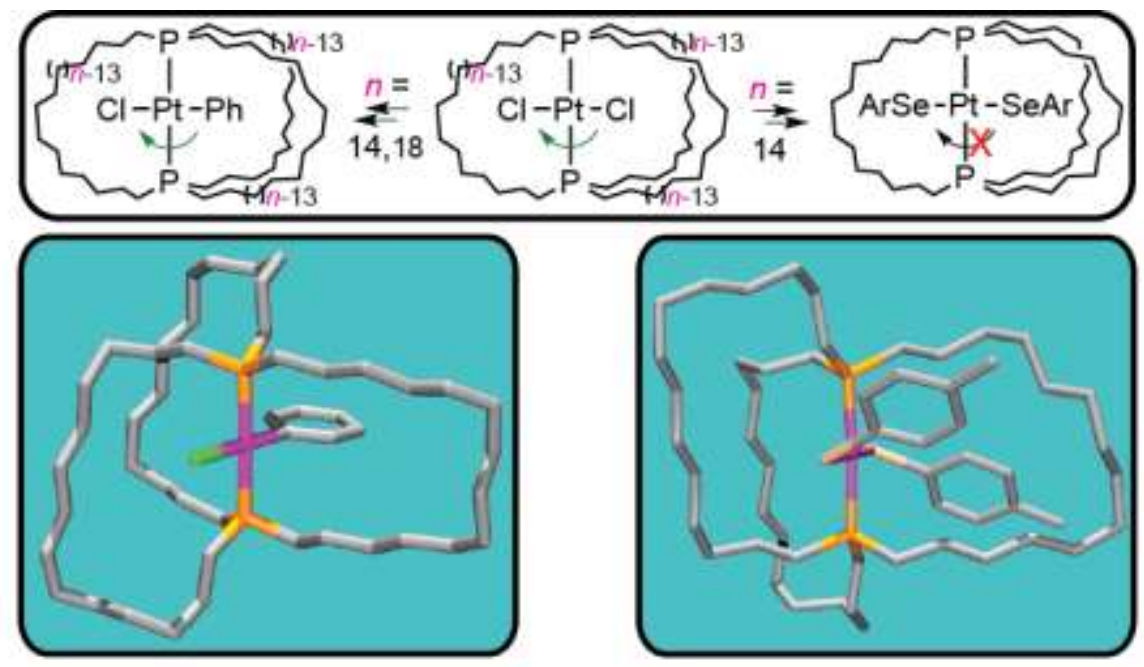




\section{(5) REFERENCES}

(1) (a) Nawara, A. J.; Shima, T.; Hampel, F.; Gladysz, J. A. J. Am. Chem. Soc. 2006, 128, 4962-4963. (b) Nawara-Hultzsch, A. J.; Stollenz, M.; Barbasiewicz, M.; Szafert, S.; Lis, T.; Hampel, F.; Bhuvanesh, N.; Gladysz, J. A. Chem. Eur. J. 2014, 20, 4617-4637.

(2) Stollenz, M.; Barbasiewicz, M.; Nawara-Hultzsch, A. J.; Fiedler, T.; Laddusaw, R. M.; Bhuvanesh, N.; Gladysz, J. A. Angew. Chem., Int. Ed. 2011, 50, 6647-6651; Angew. Chem. 2011, 123, 6777-6781.

(3) (a) Shima, T.; Hampel, F.; Gladysz, J. A. Angew. Chem., Int. Ed. 2004, 43, 55375540; Angew. Chem. 2004, 116, 5653-5656. (b) Wang, L.; Hampel, F.; Gladysz, J. A. Angew. Chem., Int. Ed. Engl. 2006, 45, 4372-4375; Angew. Chem. 2006, 118, 4479-4482. (c) Wang, L.; Shima, T.; Hampel, F.; Gladysz, J. A. Chem. Commun. 2006, 4075-4077. (d) Hess, G. D.; Hampel, F.; Gladysz, J. A. Organometallics 2007, 26, 5129-5131. (e) Skopek, K.; Gladysz, J. A. J. Organomet. Chem. 2008, 693, 857-866. (f) Estrada, A. L.; Jia, T.; Bhuvanesh, N.; Blümel, J.; Gladysz, J. A. Eur. J. Inorg. Chem. 2015, 5318-5321. (g) Fiedler, T.; Bhuvanesh, N.; Hampel, F.; Reibenspies, J. H.; Gladysz, J. A. Dalton Trans. 2016, 45, in press; DOI: 10.1039/c6dt00692b. (h) Lang, G. M.; Shima, T.; Cluff, K.; Skopek, K.; Wang, L.; Hampel, F.; Blümel, J. Gladysz, J. A. manuscript in preparation.

(4) Kottas, G. S.; Clarke, L. I.; Horinek, D.; Michl, J. Chem. Rev. 2005, 105, 1281-1376.

(5) (a) Bermudez, V.; Capron, N.; Gase, T.; Gatti, F. G.; Kajzar, F.; Leigh, D. A.; Zerbetto, F.; Zhang, S. Nature 2000, 406, 608-611. (b) Horansky, R. D.; Clarke, L. I.; Price, J. C.; Khuong, T.-A. V.; Jarowski, P. D.; Garcia-Garibay, M. A. Phys. Rev. B. 2005, B72, 014302-1 to 014302-5. (c) Horansky, R. D.; Clarke, L. I.; Winston, E. B.; Price, J. C.; Karlen, S. D.; Jarowski, P. D.; Santillan, R.; Garcia-Garibay, M. A. Phys. Rev. B 2006, 74, 054306-1 to 054306-12. (d) Dhar, P.; Swayne, C. D.; Fischer, T. M.; Kline, T.; Sen, A. Nano Lett. 2007, 7, 1010-1012. (e) Arcenegui, J. J.; García-Sánchez, P.; Morgan, H.; Ramos, A. Phys. Rev. E 2013, 88, 0330251 to $033025-8$.

(6) (a) Khuong, T.-A. V.; Nuñez, J. E.; Godinez, C. E.; Garcia-Garibay, M. A. Acc. 
Chem. Res. 2006, 39, 413-422. (b) Vogelsberg, C. S.; Garcia-Garibay, M. A. Chem. Soc. Rev. 2012, 41, 1892-1910. (c) Commins, P.; Garcia-Garibay, M. A. J. Org. Chem. 2014, 79, 16111619.

(7) (a) Nishiyama, Y.; Inagaki, Y.; Yamaguchi, K.; Setaka, W. J. Org. Chem. 2015, 80, 9959-9966 and references therein. (b) Prack, E.; O'Keefe, C. A.; Moore, J. K.; Lai, A.; Lough, A. J.; Macdonald, P. M.; Conradi, M. S.; Schurko, R. W.; Fekl, U. J. Am. Chem. Soc. 2015, 137, 13464-13467.

(8) Heß, G. D. U. doctoral dissertation, Universität Erlangen-Nürnberg, 2010; Scheme 2.6 and pp 77-78.

(9) Taher, D.; Taylor, N. J.; Corrigan, J. F. Can. J. Chem. 2009, 87, 380-385.

(10) (a) Hannu-Kuure, M. S.; Komulainen, J.; Oilunkaniemi, R.; Laitinen, R. S.; Suontamo, R.; Ahlgrén, M. J. Organomet. Chem. 2003, 666, 111-120. (b) Taher, D. Trans. Met. Chem. 2009, 34, 641-645.

(11) Praefcke, K.; Weichsel, C. Synthesis 1980, 3, 216-216.

(12) (a) Clark, H. C.; Manzer, L. E. J. Organomet. Chem. 1973, 59, 411-428. (b) Peters, T. B.; Zheng, Q.; Stahl, J.; Bohling, J. C.; Arif, A. M.; Hampel, F.; Gladysz, J. A. J. Organomet. Chem. 2002, 641, 53-61.

(13) Bondi, A. J. Phys. Chem. 1964, 68, 441-451.

(14) The distances from platinum to the two carbon atoms of each macrocycle closest to the plane of the rotator in trans-4c are 7.564/7.642 $\AA, 4.867 / 5.552 \AA$, and 5.277/5.640 $\AA$. When the van der Waals radius of carbon is subtracted from the longest and shortest distances, limiting clearances of $3.17 \AA$ and $6.28 \AA$ are obtained.

(15) $\mathrm{m} / \mathrm{z}$ (relative intensity, \%); the most intense peak of isotope envelope is given. (a) MALDI+; (b) FAB, 3-NBA.

(16) The ${ }^{1} \mathrm{H}$ and ${ }^{13} \mathrm{C}$ NMR assignments were made by analogy to those in reference $1 \mathrm{~b}$, which were established by 2D NMR experiments.

(17) This coupling represents a satellite $\left(\mathrm{d},{ }^{77} \mathrm{Se}=7.6 \%\right)$ and is not reflected in the peak 
multiplicity given.

(18) Hersh, W. H. J. Chem. Educ. 1997, 74, 1485-1489. The $J$ values given represent the apparent coupling between adjacent peaks of the triplet.

(19) This spectrum was referenced to a $\mathrm{D}_{2} \mathrm{O}$ solution of the external standard $\mathrm{K}_{2} \mathrm{PtCl}_{4}(-$ $1620 \mathrm{ppm})$.

(20) This coupling represents a satellite $\left(\mathrm{d},{ }^{195} \mathrm{Pt}=33.8 \%\right)$ and is not reflected in the peak multiplicity given.

(21) DSC and TGA data were treated as recommended by Cammenga, H. K.; Epple, M. Angew. Chem., Int. Ed. 1995, 34, 1171-1187; Angew. Chem. 1995, 107, 1284-1301. The $\mathrm{T}_{e}$ values best represent the temperature of the phase transition or exotherm.

(22) The expected platinum satellite was not observed.

(23) The $i-\mathrm{Ph}{ }^{13} \mathrm{C}$ signal was not observed.

(24) APEX2 "Program for Data Collection on Area Detectors" BRUKER AXS Inc., 5465 East Cheryl Parkway, Madison, WI 53711-5373 USA.

(25) Sheldrick, G. M., "TWINABS: Program for Absorption Correction of Area Detector Frames", Bruker AXS Inc., 5465 East Cheryl Parkway, Madison, WI 53711-5373, USA.

(26) Sheldrick, G. M. Acta Cryst. A 2008, 64, 112-122.

(27) Spek, A. L., "PLATON - A Multipurpose Crystallographic Tool" J. Appl. Cryst. 2003, 36, 7-13.; Spek, A. L., Utrecht University, Utrecht, The Netherlands 2008.

(28) Dolomanov, O. V.; Bourhis, L. J.; Gildea, R. J. Howard, J. A. K.; Puschmann, H. J. Appl. Cryst. 2009, 42, 339-341.

(29) (a) "Collect" data collection software, Nonius B.V., 1998. (b) "Scalepack" data processing software: Otwinowski, Z.; Minor, W. in Methods in Enzymology 1997, 276 (Macromolecular Crystallography, Part A), 307-326. (c) CrysAlisRED and KM-4-CCD Software. Oxford Diffraction, Wrocław, Poland, 2003.

(30) Cromer, D. T.; Waber, J. T. In International Tables for X-ray Crystallography; Ibers, J. A., Hamilton, W. C., Eds.; Kynoch: Birmingham, England, 1974. 
Table 1. Summary of Crystallographic Data.

\begin{tabular}{|c|c|c|}
\hline Compound & $\operatorname{trans}-\mathbf{3 c}$ & trans $-4 \mathbf{c}$ \\
\hline molecular formula & $\mathrm{C}_{56} \mathrm{H}_{98} \mathrm{P}_{2} \mathrm{PtSe}_{2}$ & $\mathrm{C}_{48} \mathrm{H}_{89} \mathrm{ClP}_{2} \mathrm{Pt}$ \\
\hline molecular weight & 1186.29 & 958.67 \\
\hline temp. of collection, $\mathrm{K}$ & 150.15 & $173(2)$ \\
\hline Wavelength $[\AA]$ & 0.71073 & 0.71073 \\
\hline Diffractometer & BRUKER APEX 2 & Nonius Kappa CCD \\
\hline crystal system & triclinic & monoclinic \\
\hline space group & $\mathrm{P}-1$ & $\mathrm{P} 2_{1}$ \\
\hline \multicolumn{3}{|l|}{ unit cell dimensions: } \\
\hline $\mathrm{a}[\AA]$ & $14.3291(17)$ & $13.9974(2)$ \\
\hline $\mathrm{b}[\AA]$ & $15.3338(18)$ & $13.8028(3)$ \\
\hline $\mathrm{c}[\AA \AA]$ & $15.7555(19)$ & $14.1122(3)$ \\
\hline$\alpha\left[^{\circ}\right]$ & $65.4630(10)$ & 90 \\
\hline$B\left[^{\circ}\right]$ & $70.5210(10)$ & $113.810(1)$ \\
\hline$\gamma\left[{ }^{\circ}\right]$ & $67.7030(10)^{\circ}$. & 90 \\
\hline $\mathrm{V}\left[\AA^{3}\right]$ & $2849.4(6)$ & $2494.47(8)$ \\
\hline Z & 2 & 2 \\
\hline $\mathrm{D}_{\mathrm{c}}\left[\mathrm{Mg} / \mathrm{m}^{-3}\right]$ & 1.383 & 1.276 \\
\hline$\mu\left[\mathrm{mm}^{-1}\right]$ & 3.829 & 2.959 \\
\hline crystal dimensions, $\mathrm{mm}$ & $0.07 \times 0.07 \times 0.06$ & $0.20 \times 0.20 \times 0.20$ \\
\hline$\Theta$ range $\left[{ }^{\circ}\right]$ & $1.571 \leq \Theta \leq 27.437$ & $2.16 \leq \Theta \leq 27.53$ \\
\hline range/indices $(h, k, l)$ & $-17,18 ;-17,19 ; 0,20$ & $-18,18 ;-17,17 ;-18,18$ \\
\hline no. of reflections & 12583 & 11376 \\
\hline no. of unique data & 12583 & 11376 \\
\hline no. of observed data & $10769[\mathrm{I}>2 \sigma(\mathrm{I})]$ & $10155[\mathrm{I}>2 \sigma(\mathrm{I})]$ \\
\hline no. refined parameters & 553 & 372 \\
\hline$R_{\text {int }}$ & 0.0265 & 0.000 \\
\hline \multirow[t]{2}{*}{$R$ indices $[\mathrm{I}>2 \sigma(\mathrm{I})]$} & $R_{1}=0.0327$ & $R_{1}=0.0393$ \\
\hline & $w R_{2}=0.0731$ & $w R_{2}=0.0977$ \\
\hline \multirow[t]{2}{*}{$R$ indices (all data) } & $R_{1}=0.0433$ & $R_{1}=0.0467$ \\
\hline & $w R_{2}=0.0776$ & $w R_{2}=0.1019$ \\
\hline goodness of fit & 1.005 & 1.054 \\
\hline largest diff. peak, hole $\left[\mathrm{e} \AA^{-3}\right]$ & $1.071 /-1.794$ & $2.559 /-1.035$ \\
\hline
\end{tabular}




\section{*Graphical_abstract}
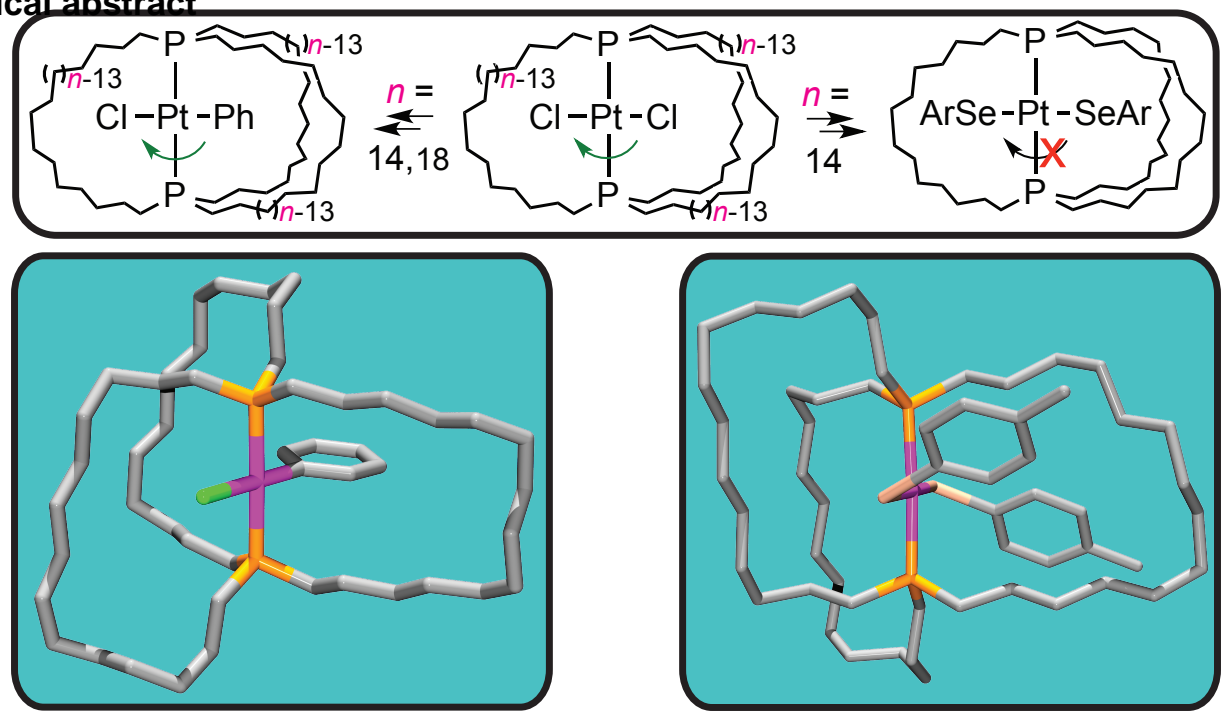